\title{
Charge structure of two tropical thunderstorms in Colombia
}

\author{
Jesús A. López ${ }^{1}$, Joan Montanyà${ }^{1}$, Oscar A. van der Velde ${ }^{1}$, Nicolau Pineda ${ }^{1,2}$, Albert \\ Salvador ${ }^{1,2}$, David Romero ${ }^{1}$, Daniel Aranguren ${ }^{3}$ John Taborda ${ }^{4}$ \\ ${ }^{1}$ Lightning Research Group, Technical University of Catalonia - BarcelonaTech, Campus \\ Terrassa, Edifici TR1, Carrer Colom, 1, 08222 Terrassa, Spain. \\ ${ }_{2}^{2}$ Meteorological Service of Catalonia, Carrer Berlín 38-46, 08029 Barcelona, Spain. \\ ${ }^{3}$ Lightning Research Group PAAS-UN, National University of Colombia, Sede Bogotá, Edificio \\ Camilo Torres - B5, Bogotá, Colombia \\ ${ }^{4}$ University of Magdalena, Electronic Engineering Department, Edificio Docente, Santa Marta, \\ Colombia
}

Corresponding author: Jesús Alberto López (jesus.alberto.lopez@upc.edu)

\section{Key Points:}

- The investigated tropical thunderstorms reveal lightning leaders at high altitudes, with a maximum height of about $16 \mathrm{~km}$.

- Lightning initiates most frequently between altitudes from $6 \mathrm{~km}$ to $14 \mathrm{~km}$.

- The analyzed Colombian tropical thunderstorms show a typical tripolar charge structure. 


\begin{abstract}
Charge structure derived from lightning leader development of tropical thunderstorms comprising equatorial latitudes of less than $\pm 10^{\circ}$ has not been investigated yet. In this work, using a Lightning Mapping Array (LMA) installed in northern Colombia, the charge structure, lightning leader initiations and the cloud-to-ground strokes rates of two thunderstorms have been analyzed. Additionally, radar information is also included. The identification of the charge regions has been obtained by analyzing the propagation of lightning leader developments. Flashes initiate between 4 and $15 \mathrm{~km}$ altitude. High initiation rates are different in the two storms. In one case the high rates are found between 8 and $13 \mathrm{~km}$. In the other case, the initiation heights are found between 10 and $15 \mathrm{~km}$. The storms show typical tripolar charge structure where the upper positive charge is present at 10 to $15 \mathrm{~km}$, the mid-level negative charge is found between 6 and $9 \mathrm{~km}$ and the lower positive charge between 4 and $6 \mathrm{~km}$ altitude. Intracloud lightning flashes with inverted polarity have been identified for a short period. In other periods, screening layer flashes have been detected at 14-15 $\mathrm{km}$.

The overall results show that the charge structures in the two Colombian storms are similar to the structures reported in North-Central Florida, but with the significant difference that the flash initiation altitudes are $2 \mathrm{~km}$ higher in Colombia. The vertical configuration of the charge regions and the leader development of these thunderstorms may help explain the occurrence of terrestrial gamma-ray flashes in tropical thunderstorms.
\end{abstract}




\section{Introduction}

Despite the fact that highest rates of global lightning activity occur in the equatorial region, electrical parameters within tropical thunderstorms are still not widely characterized. The majority of climatological and electrical studies about lightning have been conducted in temperate and subtropical zones, using both global and regional lightning location systems. One of these systems, the 3-D Lightning Mapping Array (LMA), reveals lightning processes and vertical charge structures in storms, and has been used extensively in the United States, Europe and Brazil (e.g: Lang et al., 2017, Fuchs et al., 2015; van der Velde and Montanyà, 2013; Machado et al., 2014). This contributed significantly to the understanding of mid-latitude thunderstorms. However, no 3$\mathrm{D}$ lightning mapping studies have so far been performed in the equatorial region.

As a global perspective of lightning activity, many studies derived from the space-based National Aeronautics and Space Administration Optical Transient Detector - OTD (Boccippio et al., 2000), the Tropical Rainfall Measuring Mission (TRMM) Lightning Imaging Sensor - LIS (Christian, 2003), the World Wide Lightning Location Network - WWLLN (Dowden et al., 2002; Lay et al., 2004; Collier et al., 2006) and ELF magnetic field variations (Füllekrug and FraserSmith, 1997) have provided the first global temporal and spatial distribution, which is fundamentally concentrated over land in the three tropical "chimneys": tropical South America, central Africa and the Maritime Continent (Australia and Southeast Asia) (Williams et al., 1992., Celestin and Pasko, 2011; Christian, 2003).

Some earlier studies of thunderstorms in equatorial zones have been summarized by MacGorman and Rust (1998). One of the first studies about charge configuration in tropical storms was conducted by Wang (1963), who, using electric field measurements suggested that the heights of the negative and positive charge regions were approximately located at 4 and $10 \mathrm{~km}$, respectively. Similarly, Takahashi (1978) showed that the charge structures in tropical thunderstorms in Micronesia have a comparable charge distribution as storms in mid-latitude regions, which commonly are characterized by a tripolar configuration (Williams, 1989). Other studies have suggested that the lower positive charge region seems to play an important role in initiating cloud-to-ground lightning (e.g. Pawar, 2004; Krehbiel et al., 2008; Iudin et al., 2017).

However, the development of lightning leaders has not been investigated yet in thunderstorms at the equatorial zone. Besides the interest related to the electrification of tropical thunderstorms, the almost exclusive occurrence in these storms of terrestrial gamma-ray flashes (TGFs) (Splitt et al., 2010; Fabró et al., 2015) and gigantic jets (Chen et al., 2008) motivates investigation of lightning processes and charge structures. TGFs seems to be favored by the occurrence of upward intracloud leaders at high altitudes (Williams et al., 2006). In such situation if lightning leaders are assumed to be the source of the high energetic particles those would be less attenuated (e.g. Williams et al., 2006; Xu et al., 2012). Similarly, gigantic jets are thought to originate as lightning leaders reaching high altitudes (e.g. Krehbiel et al., 2008; Liu et al., 2015; Hsu et al., 2005). Thus, both TGFs and GJs might require convection with higher cloud tops and charge regions. These conditions might be found in equatorial regions.

In this paper, we present an analysis of the charge structure of two thunderstorms derived from the lightning leader activity using a Lightning Mapping Array network. These two thunderstorms occurred on November 16, 2015, and August 3, 2017 in Colombia. 


\section{Data and methodology}

\subsection{Colombia Lightning Mapping Array - COL-LMA}

The Lighting Mapping Array (LMA) system detects radio emission sources in the very high frequency range (VHF) emitted by the electrical breakdown process of lightning channels, and employs the time-of-arrival method to locate them three-dimensionally. The maximum magnitude of the VHF source power radiation is recorded every $80 \mu \mathrm{s}$, and its time is synchronized according to a GPS-derived precise time. Each source requires detection by at least five stations to be located with an accuracy of about 50 and 100 meters in the horizontal and vertical plane, respectively. Typically, a few hundred up to a thousand or more sources are located per lightning flash. More detailed information about the LMA can be found in Rison et al., (1999) and Thomas et al., (2001, 2004).

Since the first Colombia Lightning Mapping Array (COL-LMA) system began permanent operation in the city of Santa Marta, Colombia, we have collected about 3 years of data. The COLLMA is composed of six VHF receivers with baselines between 8 and $18 \mathrm{~km}$ distributed around Santa Marta (Figure 1). The array covers part of the highest coastal mountain range in the world, Sierra Nevada de Santa Marta (in the east direction, which extends up to $5600 \mathrm{~m}$ above mean sea level), one of the biggest swamps in the country, Ciénaga Grande, and the Caribbean coastline. The two thunderstorms of this study occurred within $50 \mathrm{~km}$ from the center of the network, where the detection efficiency and location accuracy are optimal (Thomas et al., 2004; Fuchs et al., 2015).

\subsection{Colombian Total Lightning Detection Network}

Cloud-to-ground lightning activity data has been obtained from the Colombian Total Lightning Detection Network, operated by the Keraunos Colombia since 2011 (Aranguren et al., 2017). This network is composed of nineteen low frequency (VLF/LF) sensors of LINET type (Betz et al., 2009) with base-lines between 90 to $140 \mathrm{~km}$. Performance of this network can be found in Aranguren et al., (2017). It is important to mention that in this study we only consider cloud-to-ground (CG) strokes with peak current amplitudes greater than $10 \mathrm{kA}$ as suggested by Cummins et al., (1998).

\subsection{Weather radar}

Weather radar information has been obtained from the Colombia radar network operated by the Colombian Air Force (Cáceres, 2017). In the present study, the radar echo top product was used to account for the thunderstorm vertical development. We use the TOP-12 and TOP-35 radar products describing the altitudes of the 12 and $35 \mathrm{dBZ}$ reflectivity thresholds. The appearance of a $35 \mathrm{dBZ}$ or greater radar reflectivity at heights above the $-10{ }^{\circ} \mathrm{C}$ isotherm is indicative of the presence of a sufficient quantity of hydrometeors in the mixed phase region for electrical charging (e.g. Vincent et al., 2003), whereas the TOP-12 product is a proxy for the altitude of the thunderstorm top boundary (e.g. Yuter and Houze, 1995; Alcala and Dessler, 2002).

\subsection{Methodology}

Using the locations of the VHF sources provided by the LMA, it is possible to identify propagation of lightning leaders at different levels during lightning flashes (Rison et al., 1999; Rust et al., 2005). These sources are predominantly associated with breakdown processes of negative leaders moving through regions of positively charged cloud particles. Positive leaders 
that grow inside of negative charge regions are poorly detected by VHF lightning mapping systems, but often these are detectable because of recoil leader processes (retrograde negative leaders) occurring along positive leaders (Shao and Krehbiel, 1996; Mazur, 2002; Edens et al., 2012). From the identification of the leader polarities, the spatial-temporal charge structure of storms and its evolution can be deduced (Thomas et al., 2001; Mazur, 2002; Wiens et al., 2005; Weiss et al., 2008; MacGorman et al., 2014; Pineda et al., 2016).

A lightning flash identification algorithm developed by van der Velde and Montanyà (2013) is used, which in turn was adapted from Thomas et al., (2003). This method filters out noise (sources not related with lightning) by considering a specific number of sources in a grid box. The size of the grid box depends on what reduction level is chosen. Then, the algorithm performs the flash detection using a specific time separation between each consecutive sources (of those that remain after filtering). This procedure does not consider any distance criteria to further separate the sources into possible multiple flashes occurring at the same time.

The charge identification is performed by analyzing the altitudes of the LMA lighting leaders as follows. The range of heights of the LMA sources for each flash (e.g. Figure 2) is identified according to the bidirectional leader model, similar to the method introduced by Wiens et al., (2005). Lightning is assumed to initiate between oppositely charged layers. In this procedure, we exclude the early (vertical) stage of lightning development which does not necessarily form part of a charge layer ("early stage" labelled in Figure 2). Then, the polarity of each leader is identified conforming to the time-distance method introduced by van der Velde and Montanyà (2013) (an example is shown in Figure 5). Heights and polarities of each lightning leader are graphically deduced, allowing for the identification of the charge structure. We also implemented the source power analysis described in Thomas et al., (2001) as a complementary procedure to identify charge regions. The vertical distribution of source power has been used for validation of resulting charge structures derived from the time-distance plots and time-height distributions. Figure 5c shows an example of the y-z power distribution between 20:45 - 21:00 UTC on August 3, 2017. Our method only uses flashes with more than 30 sources.

Additionally, we implemented the method introduced by Caicedo et al., (2018) for the analysis of the flash initiation. If the standard deviation of the first 5 to 10 LMA sources of a flash is less than $500 \mathrm{~m}$, this region is considered compact and its centroid is assumed as the lightning flash initiation location (more detail can be found in Caicedo et al., (2018)).

The upper panel in Figure 2 shows a time-altitude plot of the LMA sources in which a bilevel IC lightning structure can be identified. In this case, the initiation of the flash was detected at a height of about $6 \mathrm{~km}$. LMA sources labeled as early stage in the upper panel correspond to the early stage of development of lightning discharge through a quasi-neutral region. The flash shows negative and positive leaders growing through opposite charge regions (the upper positive and the mid-level negative layer).

\section{Results}

\subsection{General description}

A total of 4488 flashes from two thunderstorms detected by COL-LMA on November 16, 2015, and August 3, 2017 have been analyzed. Of the total flashes, 2076 correspond to the first storm and 2412 to the second one. Both storms occurred within approximately $50 \mathrm{~km}$ of the center of the LMA array. Every single flash has been examined in concordance with the methodology 
described in the section before. For both storms, the temporal-spatial evolution of the charge structure and the altitudes of the lightning flash initiation have been analyzed. Additionally, CG strokes and weather radar information is included.

\subsection{Identification of the height of lightning initiation}

The time-altitude density maps in Figure 3 show the distribution of the initiation of lightning flashes. In addition, height of the tropopause derived from proximity soundings and weather radar information (only available for the 16 November 2015 case) are included.

In the storm of November 16, 2015, initiations of lightning flashes were distributed between 8 and $13 \mathrm{~km}$. The storm showed a first intensification in lightning activity at about 30 minutes before 19:10 UTC. At 19:10 UTC, most of lightning initiated at altitudes $9 \mathrm{~km}$. As in Williams (2003), we assume that this altitude corresponds to quasi-neutral regions being consistent with the distribution of charge centers that will be presented later (Figure 4a). At 19:30 UTC the storm presented the highest density of flash initiations, located at relatively low altitude of $8.5 \mathrm{~km}$. At 19:30 UTC cloud stroke rates rapidly increase, as well as cloud-to-ground strokes rates (Figure 4a). The highest electrical development of the storm occurs later at about 20:40 UTC. At this moment, the most typical altitude of lightning flash initiation was located at $11.5 \mathrm{~km}$ but spread in a range up to $13 \mathrm{~km}$.

From the beginning of lightning activity, the TOP-35 dBZ rapidly reached altitudes over $13 \mathrm{~km}$ until 19:50 UTC, corresponding with the period where lightning flash initiations were at lower level $(<10 \mathrm{~km})$ but with the upper positive charge region below $13 \mathrm{~km}$. After that time, lightning initiations rose to altitudes $>10 \mathrm{~km}$ while the upper positive charge region reached altitudes near $15 \mathrm{~km}$. This indicates an increase of the vertical development of the lightning activity, although the TOP-35 dBZ was at lower altitudes compared with the first hour of lightning activity of the storm. The TOP-12 dBZ was found at a constant altitude between 14 and $15 \mathrm{~km}$ during the analyzed period.

In the case of August 3, 2017, initiations of lightning flashes were mainly found above 9 $\mathrm{km}$ for the entire duration of the storm. At 20:50 UTC, shortly after the beginning of the storm, lightning initiations were found at $9 \mathrm{~km}$ coinciding with an intensification of the storm in terms of lightning and vertical development of the charge regions (Figure 4b). It only lasted for about 10 minutes. The storm intensified later at 22:00 UTC presenting typical initiations at $12.5 \mathrm{~km}$ but ranging from 10 to $<15 \mathrm{~km}$. Lightning initiation reached altitudes slightly over $15 \mathrm{~km}$ at 22:30 UTC coinciding with the maximum vertical development of the charge regions. Around and after this time, high altitude initiations of lightning flashes were related to the presence of negative charge regions at the top of the storm. We deduced the presence of screening layers after identifying electrically active regions at high altitudes (up to $14 \mathrm{~km}$ ) together with the analysis of polarities of lightning leader throughout the upper dipole as is shown in Figures 3-6. Similar to the case of November 16, 2015, the highest rates of flash initiations at high altitude close to the end of the storm were followed by an increase of CG lightning stroke rates. In August 3, 2017, initiations of these CG strokes were well distinguished at altitudes of about $6 \mathrm{~km}$.

The histograms in Figure 3 show how the initiations on November 16, 2015, were more widely distributed between 8 and $12 \mathrm{~km}$, with a mean altitude around $10 \mathrm{~km}$, whereas on August 3, 2017, the initiations had a wide distribution between 9 to $15 \mathrm{~km}$, with mean heights close to 12 
$\mathrm{km}$ and a lower peak at $5.5 \mathrm{~km}$ corresponding to the burst of initiations of cloud-to-ground strokes near the end of the storm.

\subsection{Charge structure}

Figure 4 presents the spatio-temporal evolution of the charge structure of the two analyzed thunderstorms. In addition, the figure includes total LMA lightning flash rates, cloud-to-ground discharges, radar TOP-12 dBZ and TOP-35 dBZ, height of the tropopause and temperatures at given altitudes.

The storm on November 16, 2015, (Figure 4a) exhibited a dipolar structure for the first 35 minutes while the upper positive charge region reached $12 \mathrm{~km}$ and the mid-level charge remained between 6 and $8 \mathrm{~km}$. During this period cloud-to-ground lightning activity was marginal whereas at the end of the period, the total lightning flash rates abruptly increased. This was followed by a rise of the top height of the upper positive charge region up to $13 \mathrm{~km}$. After 19:30 UTC the storm showed a tripolar charge structure and cloud-to-ground lightning activity became significant. After one hour, at 20:30 UTC, the upper positive charge region reached its highest altitude slightly below $15 \mathrm{~km}$ coinciding with the maximum LMA flash rate. During the period between 20:00 and 20:45 UTC, the tripole was elevated, lifting all the three charge regions and also the quasi-neutral region. As pointed out before, during this period the storm presented its maximum lightning activity and lightning flash initiations at 10 to $13 \mathrm{~km}$. After 20:45 UTC LMA flash rates and the tops of the upper positive charge started to decrease. The further decrease in LMA flash rates at 21:00 UTC coincides with a slightly increase of the cloud-to-ground lightning. During the storm, the upper positive charge region extended from temperatures lower than $-35^{\circ} \mathrm{C}(10 \mathrm{~km})$ up to $-75^{\circ} \mathrm{C}(15$ $\mathrm{km})$. The mid-level negative charge region was mainly located from $-5^{\circ} \mathrm{C}(6 \mathrm{~km})$ to $-24^{\circ} \mathrm{C}(9 \mathrm{~km})$. The lower positive charge region remained below the $-11^{\circ} \mathrm{C}$ level $(7 \mathrm{~km})$ to $6{ }^{\circ} \mathrm{C}(4 \mathrm{~km})$. As the storm was developing, lightning started when the TOP-35 dBZ radar reached an altitude of $10 \mathrm{~km}$. The TOP-35 dBZ reached a maximum altitude of $13 \mathrm{~km}$ between 19:00 and 19:45 UTC. From this time, the altitude of the TOP-35 dBZ remained at lower levels although the electrical activity of the storm and the top of the upper positive charge regions peaked. Lightning activity ended at the time when the TOP-35 dBZ decreased to altitudes below $10 \mathrm{~km}$.

The charge structure and lightning activity on August 3, 2017, are depicted in the Figure 4b. The storm presented a higher vertical development of the charge regions reaching altitudes up to $15 \mathrm{~km}$. This storm showed more complex charge structure than the previous. The storm exhibited dipolar structure before 20:45 UTC, between 23:15 and 23:45 UTC and between 21:30 and 22:00 UTC. For the rest, periods with a tripolar structure coincided with the presence of cloudto-ground lightning. Occasionally, a negative screening layer was present above the upper positive charge region.

In the storm of November 16, 2015, during the period between 19:15 and 19:30 UTC, some lightning flashes displayed inverted polarity structure. An example is the flash in Figure 5a. This flash initiated at about $9.5 \mathrm{~km}$ (black point in the figure) with downward negative leader propagation which extended horizontally at altitudes between 8 to $9 \mathrm{~km}$. At higher altitudes (10$11 \mathrm{~km}$ ), a few sources indicate positive leader propagation. The time-distance plot included in the same figure 5 confirms the polarity of the leaders based on their propagation speed. 


\section{Discussion}

During the mature phase of the two storms, the midlevel negative charge region was generally located between $\sim 6$ and $9.5 \mathrm{~km}$, where the temperatures given by the closest radiosonde and reanalysis data were $-5{ }^{\circ} \mathrm{C}$ to $-30{ }^{\circ} \mathrm{C}$, respectively. The upper positive charge extended from $\sim 10$ to $14.5 \mathrm{~km}$ approximately with temperatures between $-42{ }^{\circ} \mathrm{C}$ to $-70{ }^{\circ} \mathrm{C}$, respectively. The lower positive charge was found between 4 and $6 \mathrm{~km}$ corresponding to temperature levels between $6{ }^{\circ} \mathrm{C}$ to $-5{ }^{\circ} \mathrm{C}$. These altitudes of the charge regions and vertical extension of the two presented thunderstorms at latitudes less than $10^{\circ}$ in Colombia are similar to the summer multi-cell storms in North-Central Florida presented by Pilkey et al., (2014) and Caicedo et al., (2018). However, the Colombian thunderstorms of the present study have higher typical initiation altitudes. The storm on November 16, 2015 showed peaks of flash initiation at $9 \mathrm{~km}$ and $11 \mathrm{~km}$ whereas the storm on August 3, 2017 presented also peaks at high altitudes around $14 \mathrm{~km}$. In the multi-cell North-Central Florida thunderstorms in Caicedo et al., (2018), the peaks of flash initiation height were found at $5.5,7.8$ and $8.8 \mathrm{~km}$. In Colombia the peaks of flash initiation correspond colder temperatures (e.g. $-35^{\circ} \mathrm{C}$ at $11 \mathrm{~km}$ on November 16, 2015) than the temperatures in North-Central Florida (e.g. $<-20^{\circ} \mathrm{C}$ ). This indicates that in the Colombian storms the predominant initiation occurred between the opposite charge regions of the main layers. The initiations around $-35^{\circ} \mathrm{C}$ are consistent with a peak of LMA source activity in quasi-neutral regions, similar to the isolated convective storms with normal polarity charge structure in northern Alabama, Washington DC and central Oklahoma investigated by (Fuchs et al., 2015; Fuchs and Rutledge, 2018). The range of the flash initiation altitudes between the mid-level negative region and upper positive layer is similar in Colombia $(\sim 2.3 \mathrm{~km})$ and North Florida $(2-3 \mathrm{~km})$. Summing up, the charge structures found in the two Colombian storms are similar to the ones reported in North-Central Florida but with significant differences found in the height of the initiation peak of LMA sources that are about 2-3 km higher in Colombia.

In addition, lightning flash activity started when the radar echo TOP $35 \mathrm{dBZ}$ reached 10 $\mathrm{km}$ and ended when this reflectivity returned below that altitude. During the storm lifecycle, the TOP $35 \mathrm{dBZ}$ remained above $10 \mathrm{~km}$ with maximum tops at more than $13 \mathrm{~km}$. Caicedo et al., (2018) found the initiation of lightning activity when the TOP $45 \mathrm{dBZ}$ reached $9 \mathrm{~km}$ which can indicate that the storms in North-Central Florida developed under more intense convective conditions than the investigated thunderstorms in Colombia.

In terms of number of lightning flashes, the thunderstorm on November 16, 2015, produced 95 -CG strokes and 2076 intracloud flashes whereas the thunderstorm on August 3, 2017, reported $106-\mathrm{CG}$ strokes and 2412 intracloud flashes. This results in a percentage of intracloud flashes of $95 \%$ which is similar to the 90.7-97.9\% found in the investigated storms in North-Central Florida by Caicedo et al., (2018). The two Colombian thunderstorms produced maximum total lightning rates of $\sim 25 \mathrm{~min}^{-1}$ being lower than the maximum flash rates in the compared storms in Florida, but similar in the overall rates $\left(<20 \mathrm{~min}^{-1}\right)$ during the same Floridian storm lifetimes. On the other hand, the cloud-to-ground stroke rates of the two thunderstorms in this work (Figure 4) are much lower than the ones reported in Colombia by Inampués (2013) with maximum stroke rates of 27 $\mathrm{min}^{-1}$. That indicates that the two presented storms cannot be classified as intense in terms of CG rates. Despite the low CG rates, it is worth mentioning that the low positive charge layers were clearly identified during periods of enhancement of CG occurrence. This is in agreement with the mechanism described by Krehbiel et al., (2008) and the observations in the tropics by Pawar (2004). A more recent study on this topic can be found in Iudin et al., (2017). 
The analyzed storms also have shown initiation peaks of the LMA sources related to the early stage of development of lightning above the positive charge center, indicating the formation of screening layers. The absence of a screening layer would not allow initiation above the upper positive charge layer in the same manner that the absence of a lower positive charge prevents the occurrence of cloud-to-ground flashes (see e.g., Krehbiel et al., 2008 and references therein). The identified breakdown events involving flashes initiated above the upper positive charge with few tens of sources are similarly to those reported by Bruning et al., (2010) in a central Oklahoma supercell. No specific indications are provided in Caicedo et al., (2018) and Pilkey et al., (2014) related to the occurrence of breakdown involving screening layers but some of their multi-cell storms have similar charge structure to the cases presented here. Further investigations of the occurrence of breakdown involving upper screening layers in Colombian thunderstorms are still needed, but as far as the authors have found analyzing thunderstorms in that area these flashes can be common. Table 1 summarizes our main findings from the two analyzed thunderstorms in Colombia.

In the case of the two analyzed thunderstorms, we have shown that lightning flashes in Colombia can achieve high altitudes $\sim 15 \mathrm{~km}$ (Figure 6), which is of significant interest for the characterization of the electrical conditions of tropical thunderstorms favorable for the production of TGFs as well as GJs. Based on the analyzed charge structures and the presence of negative leaders at high altitudes these thunderstorms are of the type favorable of TGFs production as described by Chronis et al., (2016). In Lu et al., (2010) a TGF was correlated with an IC lightning flash derived from the North Alabama Lightning Mapping Array whose charge structure exhibited a bipolar configuration centered at 8.5 and $13 \mathrm{~km}$ for the mid-level and the upper positive layers, respectively. This storm had cloud tops between 13 and $16 \mathrm{~km}$. In addition, Cummer et., al (2015) found that TGFs are produced several milliseconds after lightning leader initiations associated with radio pulses located at altitudes between 9.4 and $11.2 \mathrm{~km}$. We have shown that the two analyzed storms produce typical lightning initiations in these ranges.

\section{Conclusions}

Summarizing, this paper has presented the first characterization of the electrical behavior of the two tropical thunderstorms in South America at latitudes less than $\pm 10^{\circ}$ using a Lightning Mapping Array. Volumetric weather radar data has been also included in this study. The following conclusions are summarized:

- The two storms revealed the presence of lightning leaders at altitudes up to $16 \mathrm{~km}$.

- In general, the altitudes of the charge regions are similar to those found in literature of multi-cells in North-Central Florida.

- Lightning initiations peaked at altitudes of 9-10 km and $14 \mathrm{~km}$, those are higher than those in the compared thunderstorms in Florida.

- The peaks of the LMA sources related to the upper positive charge and the midlevel negative charge regions are about $2-3 \mathrm{~km}$ higher in the Colombia than in the NorthCentral Florida storms.

- Flashes involving upper screening layers up to $15 \mathrm{~km}$ have been identified. 
- Lightning activity initiated when the radar echo TOP $35 \mathrm{dBZ}$ reached $10 \mathrm{~km}$ and ended when this reflectivity returned below that altitude. The altitude of the TOP $12 \mathrm{dBZ}$ coincided with the maximum altitude of the upper positive charge region.

- $\mathrm{CG}$ activity was predominant during the presence of the lower positive charge region.

- Lightning flashes with a bi-level inverted structure have been identified.

To conclude, besides the meteorological information provided in this paper, the results are of interest for the understanding of the almost exclusive production of TGFs in tropical thunderstorms. We have shown that the charge structures, altitudes of negative lightning leaders and initiation of lightning flashes in the analyzed storms fulfill the predicted and reported conditions of occurrence of TGFs investigated by other authors.

\section{Acknowledgments}

This work was supported by research grants from the Spanish Ministry of Economy and the European Regional Development Fund (FEDER): ESP2013-48032-C5-3-R, ESP2015-69909C5-5-R and ESP2017-86263-C4-2-R.

The authors are grateful to Keraunos for providing lightning data. Also, we would like to thank the Colombian governmental institutions AEROCIVIL and FAC for providing the weather radar information.

The data derived from the Colombia LMA network are available in the supporting information. 


\section{References}

Alcala, C., \& Dessler, A. (2002). Observations of deep convection in the tropics using the Tropical Rainfall Measuring Mission (TRMM) precipitation radar. Journal of Geophysical Research, 107(D24), 4792. https://doi.org/10.1029/2002JD002457

Aranguren, D., López, J., Inampués, J., Torres, H., \& Betz, H. (2017). Cloud-to-ground lightning activity in Colombia and the influence of topography. Journal of Atmospheric and SolarTerrestrial Physics, 154, 182-189. https://doi.org/10.1016/j.jastp.2016.08.010

Betz, H., Schmidt, K., \& Oettinger, W. (2009). LINET-An international VLF/LF lightning detectionnetwork in Europe. In Lightning: Principles, Instruments and Applications. Springer. https://doi.org/10.1007/978-1-4020-9079-0_5

Boccippio, D., Koshak, W., Blakeslee, R., Driscoll, K., Mach, D., Buechler, D., Boeck, W., Christian,H. J., \& Goodman, S. J. (2000). The optical transient detector (OTD): Instrument characteristics and cross-sensor validation. Journal of Atmospheric and Oceanic Technology, 17(4), 441-458. https://doi.org/10.1175/1520-0426(2000)017<0441:TOTDOI>2.0.CO;2

Bruning, E., Rust, D., MacGorman, D., Biggerstaff, M., \& Schuur, T. (2010). Formation of charge structures in a supercell. Monthly Weather Review, 138(10), 3740-3761. https://doi.org/10.1175/2010MWR3160.1

Cáceres, R. (2017). Radar meteorológico. In Meteorología aplicada a la seguridad de lasoperaciones aéreas. Colección Ciencia y Poder Aéreo No. 12, pp 200-219. Bogotá-Colombia. ISBN: 978-958-59961-1-3

Celestin, S., \& Pasko, V. (2011). Energy and fluxes of thermal runaway electrons produced by exponential growth of streamers during the stepping of lightning leaders and in transient luminous events. Journal of Geophysical Research, 116, A03315. https://doi.org/10.1029/2010JA016260

Chen, A., Kuo, C., Lee, Y., Su, H., Hsu, R., Chern, J., Frey, H., Mende, S., Takahashi, Y., Fukunishi, H., Chang, Y., Liu, T., \& Lee, L. (2008). Global distributions and occurrence rates of transient luminous events. Journal of Geophysical Research, 113, A08306.

https://doi.org/10.1029/2008JA013101

Christian, H. (2003). Global frequency and distribution of lightning as observed from space by the Optical Transient Detector. Journal of Geophysical Research, 108(D1), 4005. https://doi.org/10.1029/2002JD002347

Chronis, T., Briggs, M., Priftis, G., Connaughton, V., Brundell, J., Holzworth, R., Heckman, S., McBreen, S., Fitzpatrick, G., \& Stanbro, M. (2016). Characteristics of thunderstorms that produce terrestrial gamma ray flashes. American Meteorological Society, 97(4), 639-653. https://doi.org/10.1175/BAMS-D-14-00239.1

Collier, A., Hughes, A., Lichtenberger, J., \& Steinbach, P. (2006). Seasonal and diurnal variation of lightning activity over southern Africa and correlation with European whistler observations. Annales Geophysicae, 24(2), 529-542. https://doi.org/10.5194/angeo-24-529-2006 
Cummer, S., Lyu, F., Briggs, M., Fitzpatrick, G., Roberts, O., \& Dwyer, J. (2015). Lightning leader altitude progression in terrestrial gamma-ray flashes. Geophysical Research Letters, 42, 7792-7798. https://doi.org/10.1002/2015GL065228

Cummins, K., Murphy, M., Bardo, E., Hiscox, W., Pyle, R., \& Pifer, A. (1998). A combined TOA/MDF technology upgrade of the US National Lightning Detection Network. Journal of Geophysical Research, 10 3(D8), 9035-9044. https://doi.org/10.1029/98JD00153

Dowden, R., Brundell, J., \& Rodger, C. (2002). VLF lightning location by time of group arrival (TOGA) at multiple sites. Journal of Atmospheric and Solar-Terrestrial Physics., 64(7), 817-830. https://doi.org/0.1016/S1364-6826(02)00085-8

Edens, H., Eack, K., Eastvedt, E., Trueblood, J., Winn, W., Krehbiel, P., Aulich, G., Hunyady, S., Murray, W., Rison, W., Behnke, S., \& Thomas, R. (2012). VHF lightning mapping observations of a triggered lightning flash. Geophysical Research Letters, 39, L19807. https://doi.org/10.1029/2012GL053666

Fabró, F., Montanyà, J., Marisaldi, M., van der Velde, O., \& Fuschino, F. (2015). Analysis of global terrestrial gamma ray flashes distribution and special focus on AGILE detections over South America. Journalof Atmospheric and Solar-Terrestrial Physics, 124, 10-20. https://doi.org/10.1016/j.jastp.2015.01.009

Fuchs, B., \& Rutledge, S. (2018). Investigation of lightning flash locations in isolated convection using LMA observations. Journal of Geophysical Research: Atmospheres, 77, 5916-5925. https://doi.org/10.1128/AEM.00611-11

Fuchs, B., Rutledge, S., Bruning, E., Pierce, J., Kodros, J., Lang, T., MacGorman, D., Krehbiel, P., \&Rison, W. (2015). Environmental controls on storm intensity and charge structure in multiple regions of the continental United States. Journal of Geophysical Research: Atmospheres, 120, 6575-6596. https://doi.org/10.1002/2015JD023271

Füllekrug, M., \& Fraser-Smith, A. (1997). Global lightning and climate variability inferred from ELF magnetic field variations. Geophysical Research Letters, 24(19), 2411-2414. https://doi.org/10.1029/97GL02358

Hsu, R., Chen, A., Kuo, C., Lee, Y., Su, H., Fukunishi, H., Takahashi, Y., Adachi, T., Yamamoto, K.,Frey, H., Mende, S., \& Lee, L. (2005). Gigantic jet observation by the ISUAL payload of FORMOSAT-2 satellite. AGU Fall Meeting Abstracts, 114(A4). https://doi.org/10.1029/2008JA013791

Inampués, J. (2013). Integración de los sistemas de alerta de tormentas eléctricas en redes inteligentes autor: IE (Master dissertation, Universidad Nacional de Colombia), 91-137. URL: http://bdigital.unal.edu.co/46302/1/822308.2014.pdf

Iudin, D., Rakov, V., Mareev, E., Iudin, F., Syssoev, A., \& Davydenko, S. (2017). Advanced numericalmodel of lightning development: Application to studying the role of LPCR in 
determining lightning type. Journal of Geophysical Research: Atmospheres, 122, 6416-6430. https://doi.org/10.1002/2016JD026261

Krehbiel, P., Riousset, J., Pasko, V., Thomas, R., Rison, W., Stanley, M., \& Edens, H. (2008). Upward electrical discharges from thunderstorms. Nature Geoscience, 1(4), 233-237. https://doi.org/10.1038/ngeo162

Lang, T. J., Pédeboy, S., Rison, W., Cerveny, R. S., Montanyà, J., Chauzy, S., MacGorman, D. R., Holle, R. L., Ávila, E. E., Zhang, Y., Carbin, G., Mansell, E. R., Kuleshov, Y., Peterson, T. C., Brunet, M.,Driouech, F., \& Krahenbuhl, D. S. (2017). WMO world record lightning extremes: Longest reported flashdistance and longest reported flash duration. Bulletin of the American Meteorological Society, 98(6), 1153-1168. https://doi.org/10.1175/BAMS-D-160061.1

Lay, E., Holzworth, R., Rodger, C., Thomas, J., Pinto, O., \& Dowden, R. (2004). WWLLN global lightning detection system: Regional validation study in Brazil. Geophysical Research Letters, 31, L03102. https://doi.org/10.1029/2003GL018882

Liu, N., Spiva, N., Dwyer, J., Rassoul, H., Free, D., \& Cummer, S. (2015). Upward electrical discharges observed above Tropical Depression Dorian. Nature Communications, 6(1), 5995. https://doi.org/10.1038/ncomms6995

Lu, G., Blakeslee, R., Li, J., Smith, D., Shao, X., McCaul, E., Buechler, D., Christian, H., Hall, J., \& Cummer, S. (2010). Lightning mapping observation of a terrestrial gamma-ray flash. Geophysical Research Letters, 37, L11806. https://doi.org/10.1029/2010GL043494

MacGorman, D., Biggerstaff, M., Waugh, S., Pilkey, J., Uman, M., Jordan, D., and Betten, D. (2014). Coordinated LMA, balloon-borne electric field, and polarimetric radar observations of a triggered lightningflash at Camp Blanding. XV International Conference on Atmospheric Electricity, Norman, Oklahoma (pp. 15-20).

MacGorman, D., \& Rust, W. (1998). The electrical nature of storms. Oxford: Oxford University. Machado, L. A., Silva Dias, M. A., Morales, C., Fisch, G., Vila, D., Albrecht, R., Goodman, S. J., Calheiros, A. J., Biscaro, T., Kummerow, C., \& Cohen, J. (2014). The Chuva Project: How does convection vary across Brazil? Bulletin of the American Meteorological Society, 95(9), 1365-1380. https://doi.org/10.1175/BAMS-D-13-00084.1

Mazur, V. (2002). Physical processes during development of lightning flashes. Comptes Rendus Physique, 3(10), 1393-1409. https://doi.org/10.1016/S1631-0705(02)01412-3

Pawar, S. (2004). Evolution of lightning and the possible initiation/triggering of lightning discharges by the lower positive charge center in an isolated thundercloud in the tropics. Journal of Geophysical Research, 109, D02205. https://doi.org/10.1029/2003JD003735

Pilkey, J., Uman, M., Hill, J., Ngin, T., Gamerota, W., Jordan, D., Caicedo, J., \& Hare, B. (2014). Rocket-triggered lightning propagation paths relative to preceding natural lightning 
activity and inferred cloud charge. Journal of Geophysical Research: Atmospheres, 119, 13,42713,456. https://doi.org/10.1002/2014JD022139

Pineda, N., Rigo, T., Montanyà, J., \& van der Velde, O. (2016). Charge structure analysis of a severe hailstorm with predominantly positive cloud-to-ground lightning. Atmospheric Research, 178-179, 31-44. https://doi.org/10.1016/j.atmosres.2016.03.010

Rison, W., Thomas, R., Krehbiel, P., Hamlin, T., \& Harlin, J. (1999). A GPS-based threedimensional lightning mapping system: Initial observations in central New Mexico. Geophysical Research Letters, 26(23), 3573-3576. https://doi.org/10.1029/1999GL010856

Rust, D., MacGorman, D., Bruning, E., Weiss, S., Krehbiel, P., Thomas, R., Rison, W., Hamlin, T., \& Harlin, J. (2005). Inverted-polarity electrical structures in thunderstorms in the Severe Thunderstorm Electrification and Precipitation Study (STEPS). Atmospheric Research, 76(1-4), 247-271. https://doi.org/10.1016/j.atmosres.2004.11.029

Shao, X., \& Krehbiel, P. (1996). The spatial and temporal development of intracloud lightning. Journal of Geophysical Research, 101(D21), 26,641-26,668. https://doi.org/10.1029/96JD01803

Splitt, M., Lazarus, S., Barnes, D., Dwyer, J., Rassoul, H., Smith, D., Hazelton, B., \& Grefenstette, B. (2010). Thunderstorm characteristics associated with RHESSI identified terrestrial gamma ray flashes. Journal of Geophysical Research, 115, A00E38. https://doi.org/10.1029/2009JA014622

Takahashi, T. (1978). Electrical properties of oceanic tropical clouds at Ponape, Micronesia. Journal Monthly Weather Review, 106, 1598-1612. https://doi.org/10.1175/15200493(1978)106<1598:EPOOTC>2.0.CO;2

Thomas, R., Krehbiel, P., Hamlin, T., Harlin, J., \& Shown, D. (2001). Observations of VHF source powers radiated by lightning. Geophysical Research Letters, 28(1), 143-146. https://doi.org/10.1029/2000GL011464

Thomas, R., Krehbiel, P., Rison, W., Harlin, J., Hamlin, T., \& Campbell, N. (2003). The LMA flash algorithm. Conference on Atmospheric Electricity, (pp. 655-656). France: International Commission on Atmospheric Electricity Versailles.

Thomas, R., Krehbiel, P., Rison, W., Hunyady, S., Winn, W., Hamlin, T., \& Harlin, J. (2004). Accuracy of the lightning mapping array. Journal of Geophysical Research, 109, D14207. https://doi.org/10.1029/2004JD004549

Van Der Velde, O., \& Montanyà, J. (2013). Asymmetries in bidirectional leader development of lightning flashes. Journal of Geophysical Research: Atmospheres, 118, 13,504-13,519. https://doi.org/10.1002/2013JD020257 
Vincent, B., Carey, L., Carolina, N., Schneider, D., Keeter, K., and Gonski, Rod. (2003). Using WSR-88D reflectivity data for the prediction of cloud-to-ground lightning: A North Carolina study. National Weather Digest.

Wang, C. P. (1963). Lightning discharges in the tropics: Whole discharges. Journal of Geophysical Research, 68(7), 1943-1949. https://doi.org/10.1029/jz068i007p01943

Weiss, S., Rust, D., MacGorman, D., Bruning, E., \& Krehbiel, P. (2008). Evolving complex electrical structures of the STEPS 25 June 2000 Multicell Storm. Monthly Weather Review, 136(2), 741-756. https://doi.org/10.1175/2007MWR2023.1

Wiens, K., Rutledge, S., \& Tessendorf, S. (2005). The 29 June 2000 supercell observed during STEPS. Part II: Lightning and charge structure. Journal of the Atmospheric Sciences, 62(12), 4151-4177. https://doi.org/10.1175/JAS3615.1

Williams, E. (1989). The tripole structure of thunderstorms. Journal of Geophysical Research, 94(D11), 13,151. https://doi.org/10.1029/JD094iD11p13151

Williams, E. (2003). Charge structure and geographical variation of thunderclouds. In The lightning flash, (pp. 1-12). London, UK: Institution of Engineering and Technology.

https://doi.org/10.1049/PBPO034E

Williams, E., Boldi, R., Bór, J., Sátori, G., Price, C., Greenberg, E., Takahashi, Y., Yamamoto, K., Matsudo, Y., Hobara, Y., Hayakawa, M., Chronis, T., Anagnostou, E., Smith, D., \& Lopez, L. (2006). Lightning flashes conducive to the production and escape of gamma radiation to space. Journal of Geophysical Research, 111, D16209. https://doi.org/10.1029/2005JD006447

Williams, E., Geotis, S., Renno, N., Rutledge, S., Rasmussen, E., \& Rickenbach, T. (1992). A radar and electrical study of tropical "hot towers". Journal of the Atmospheric Sciences, 49(15), 1386-1395. https://doi.org/10.1175/1520-0469(1992)049<1386:ARAESO>2.0.CO;2

Xu, W., Celestin, S., \& Pasko., and Victor, P. (2012). Source altitudes of terrestrial gamma-ray flashes produced by lightning leaders. Geophysical Research Letters, 39, L08801. https://doi.org/10.1029/2012GL051351

Yuter, S. E., \& Houze, R. (1995). Three-dimensional kinematic and microphysical evolution of Florida Cumulonimbus. Part II: Frequency distributions of vertical velocity, reflectivity, and differential reflectivity. Monthly Weather Review, 123(7), 1941-1963. https://doi.org/10.1175/1520-0493(1995)123<1941:TDKAME>2.0.CO;2 
Table and Figure captions

Table 1. Summary of the main characteristics obtained from two thunderstorms in Colombia.

Figure 1. Geographical location of Colombia and the Colombia Lightning Mapping Array network -COL-LMA.

Figure 2. LMA multi-panel plot for a single flash detected on August 3, 2017. The upper panel shows a time-altitude plot of the flash; the left panel is a plan view of longitude versus latitude coordinates with elevation contour lines in color. The right panels show the height of the LMA sources versus latitude and longitude. The LMA sources (dots) are colored by time. The black triangles are the COL-LMA sensors.

Figure 3. Spatial and temporal density of the lightning flash initiation. The histograms on the right show the frequency distribution of the initiation heights. TOP-12 dBZ (dotted line), TOP-35 dBZ (dashed line), Tropopause altitude (solid line). For the 16 November 2015 case, the height of the tropopause was deduced from the closest radiosonde. In the case of August 3, 2017, the height of the tropopause was determined from reanalysis.

Figure 4. Charge distribution of the two analyzed storms. Negative CG stroke rate (red dashed line), positive CG stroke rate (red dotted line), TOP-12 dBZ (black dotted line), TOP-35 dBZ (black dashed line), Tropopause altitude (black solid line) and LMA flash rate (blue solid line).

Figure 5. Example of an inverted polarity flash. a) Plant view and side views of the LMA sources as described in Figure 2. b) Time-distance plot (van der Velde and Montanyà, 2013). The slope of the dashed lines corresponds to typical positive leader speeds $\left(2 \cdot 10^{4} \mathrm{~m} \mathrm{~s}^{-1}\right)$ and negative leader speeds $\left(10^{5} \mathrm{~m} \mathrm{~s}^{-1}\right.$ and $\left.10^{6} \mathrm{~m} \mathrm{~s}^{-1}\right)$. c) Source power of the sources during 15 minutes of the storm on August 3, 2017. A tripolar charge distribution is identified. Sources in a) and b) are colored by time whereas in c) are colored by power.

Figure 6. Same as Figure 2, except for an interval of 20 seconds with high altitude breakdown (High-alt) that occurs above the upper positive charge region. 
Table 1. Summary of the main characteristics obtained from two thunderstorms in Colombia.

Variable

Total flashes
Total -CG
Maximum LMA flash rates $\left(\mathrm{min}^{-1}\right)$
Maximum -CG stroke rates $\left(\mathrm{min}^{-1}\right)$
Maximum height of the LMA flash initiation
(km)
Range of the upper positive charge and
temperature* $(\mathrm{km}) ;\left({ }^{\circ} \mathrm{C}\right)$
Range of the Midlevel negative charge and
temperature*
Range of the lower positive charge and
temperature*

Altitude of the tropopause $(\mathrm{km})$
November 16, 2015

August 3, 2017

2076
95
27
$\sim 3$
11
$\mathrm{~km}$ to $15 \mathrm{~km} ;$
${ }^{\circ} \mathrm{C}$ to $-75^{\circ} \mathrm{C}$
$\mathrm{m}$ to $9.5 \mathrm{~km}$
${ }^{\circ} \mathrm{C}$ to $-30^{\circ} \mathrm{C}$
$\mathrm{km}$ to $7 \mathrm{~km}$
$\sim 16$
$\sim 16$

2412
106
22
$\sim 4$
14

$11 \mathrm{~km}$ to $14 \mathrm{~km}$ $-55^{\circ} \mathrm{C}$ to $71^{\circ} \mathrm{C}$

$6 \mathrm{~km}$ to $9 \mathrm{~km}$ $-7^{\circ} \mathrm{C}$ to $-36^{\circ} \mathrm{C}$ $5 \mathrm{~km}$ to $6 \mathrm{~km}$ $3^{\circ} \mathrm{C}$ to $-7^{\circ} \mathrm{C}$ $\sim 16$

\footnotetext{
$*$ Value obtained during mature stage of storm.
} 
Figure 1.

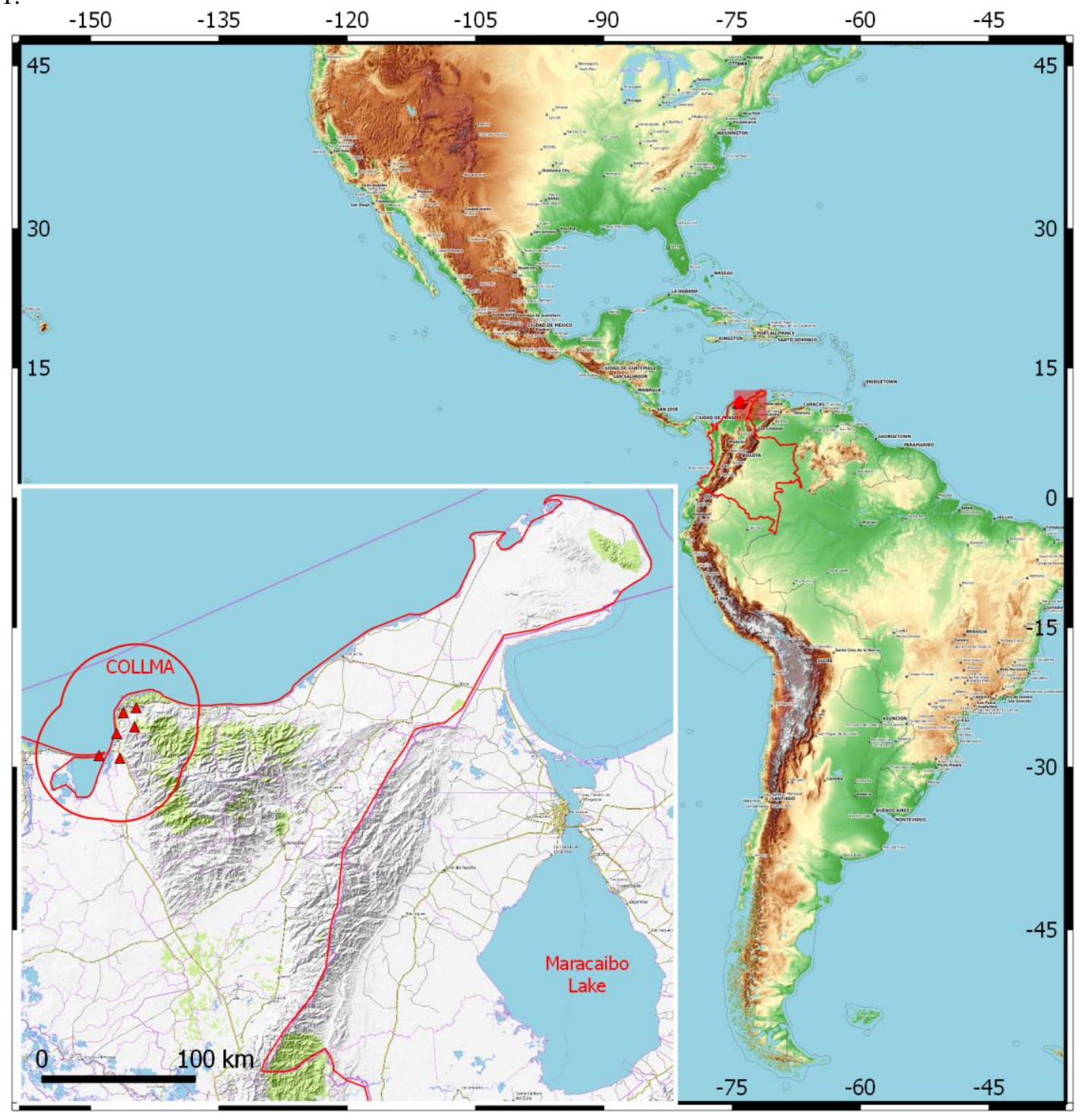


Figure 2.
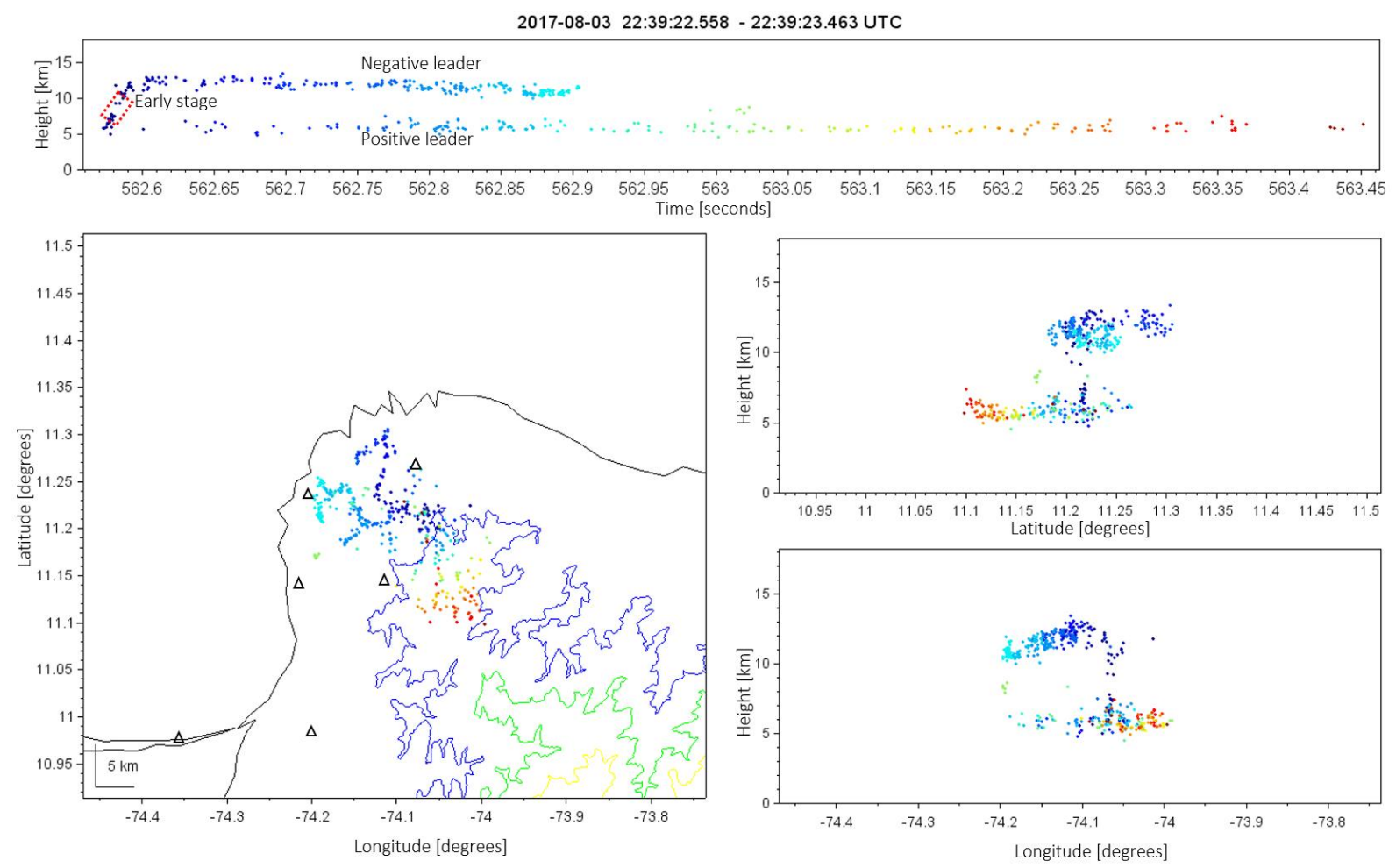
Figure 3.

a) Storm on November 16, 2015

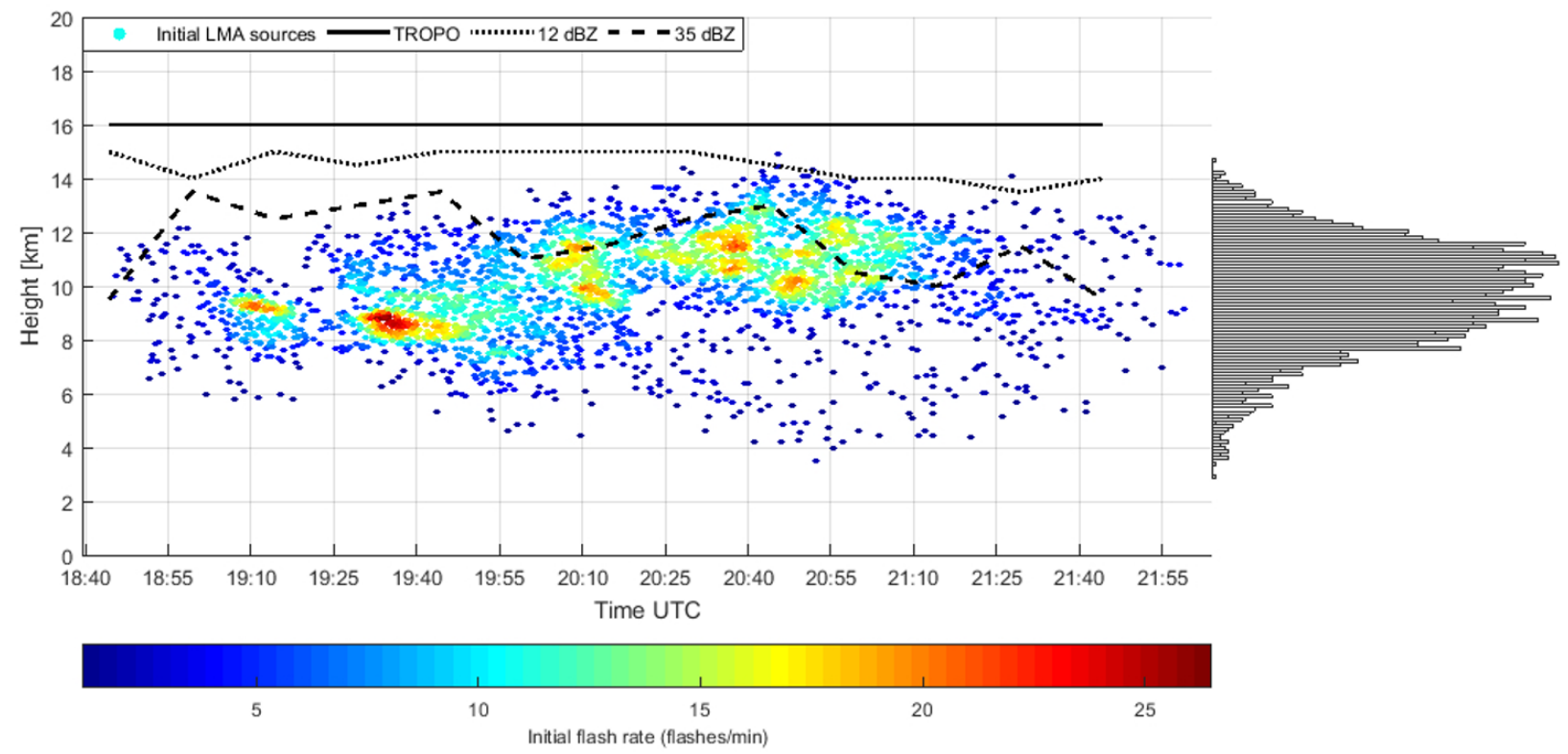

b) Storm on August 3, 2017
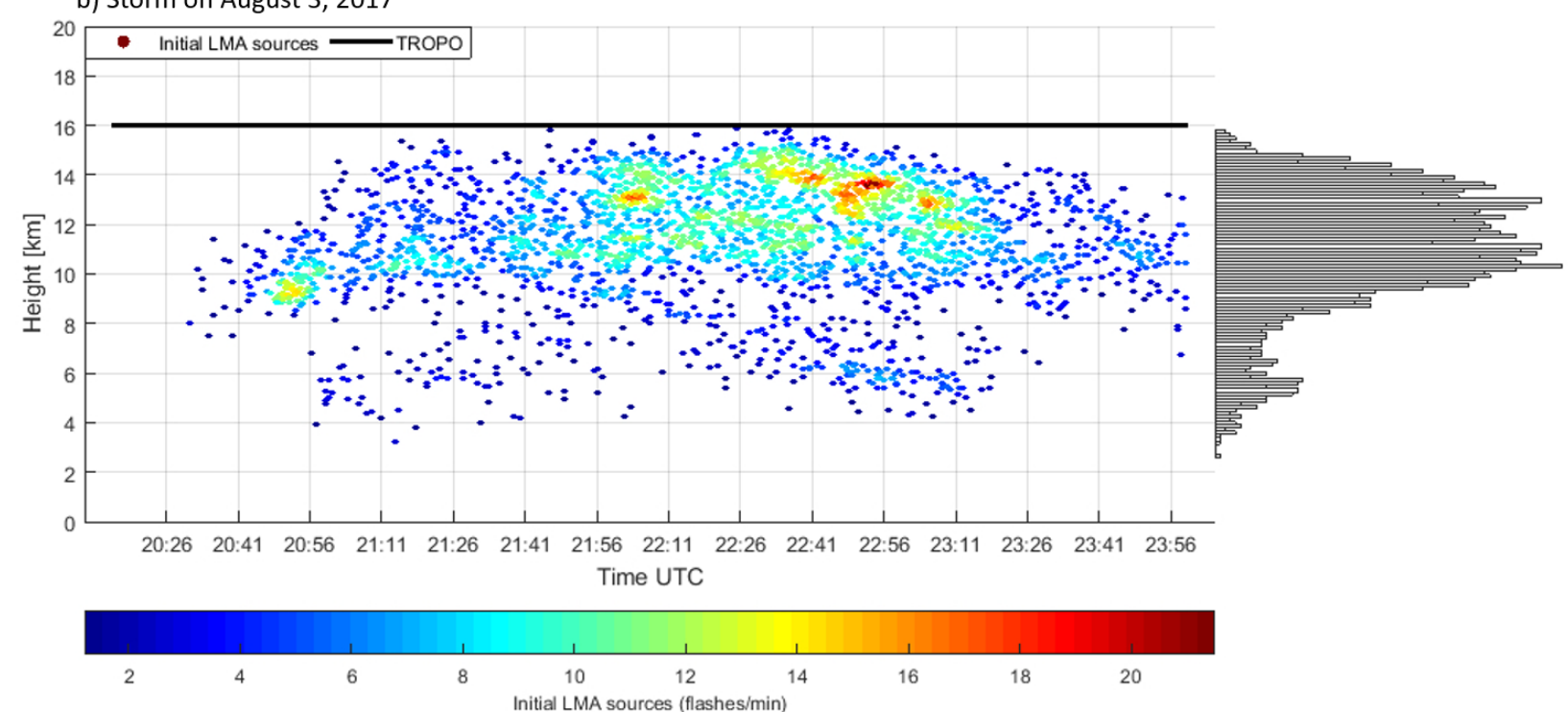
Figure 4.

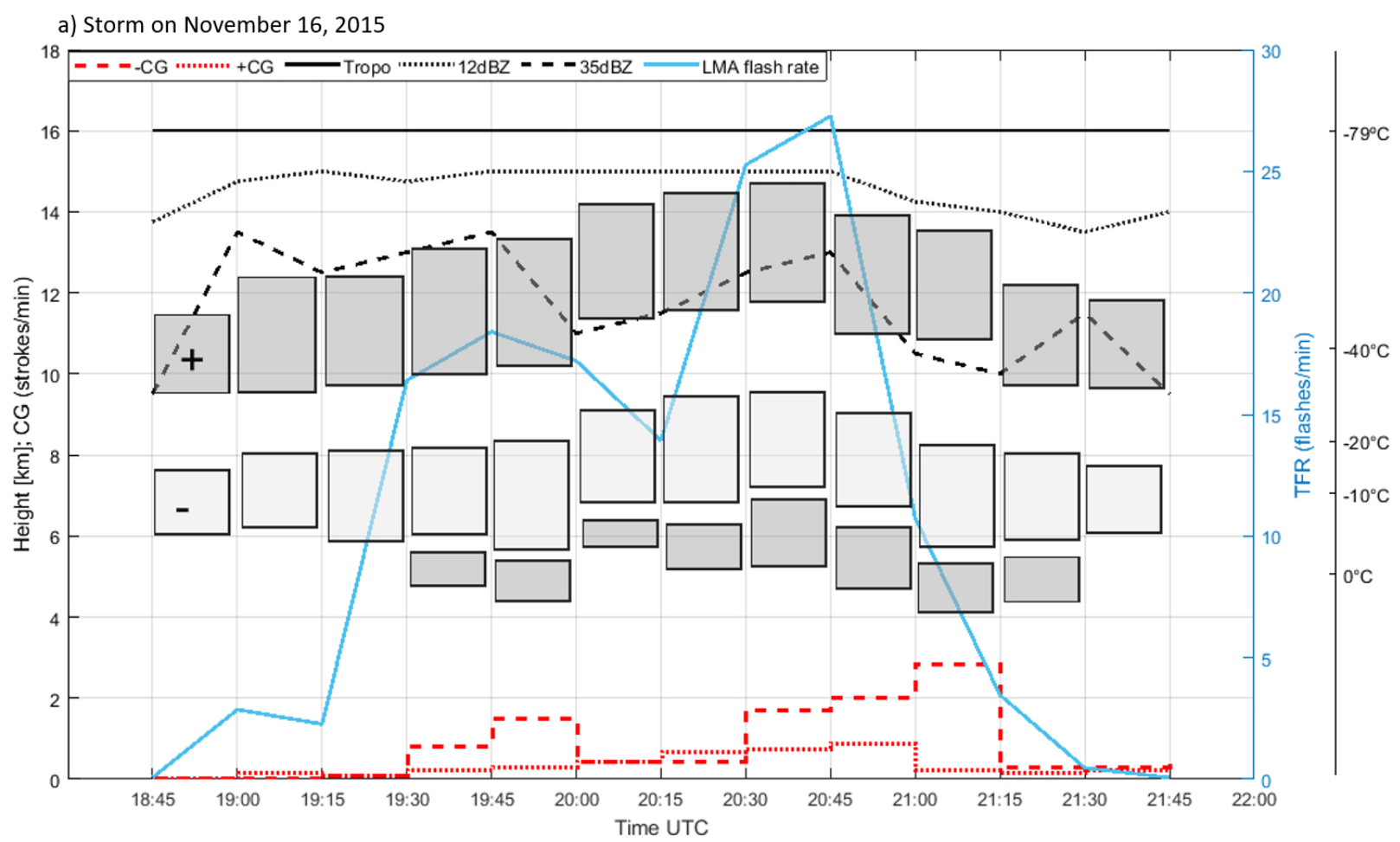

b) Storm on August 3, 2017

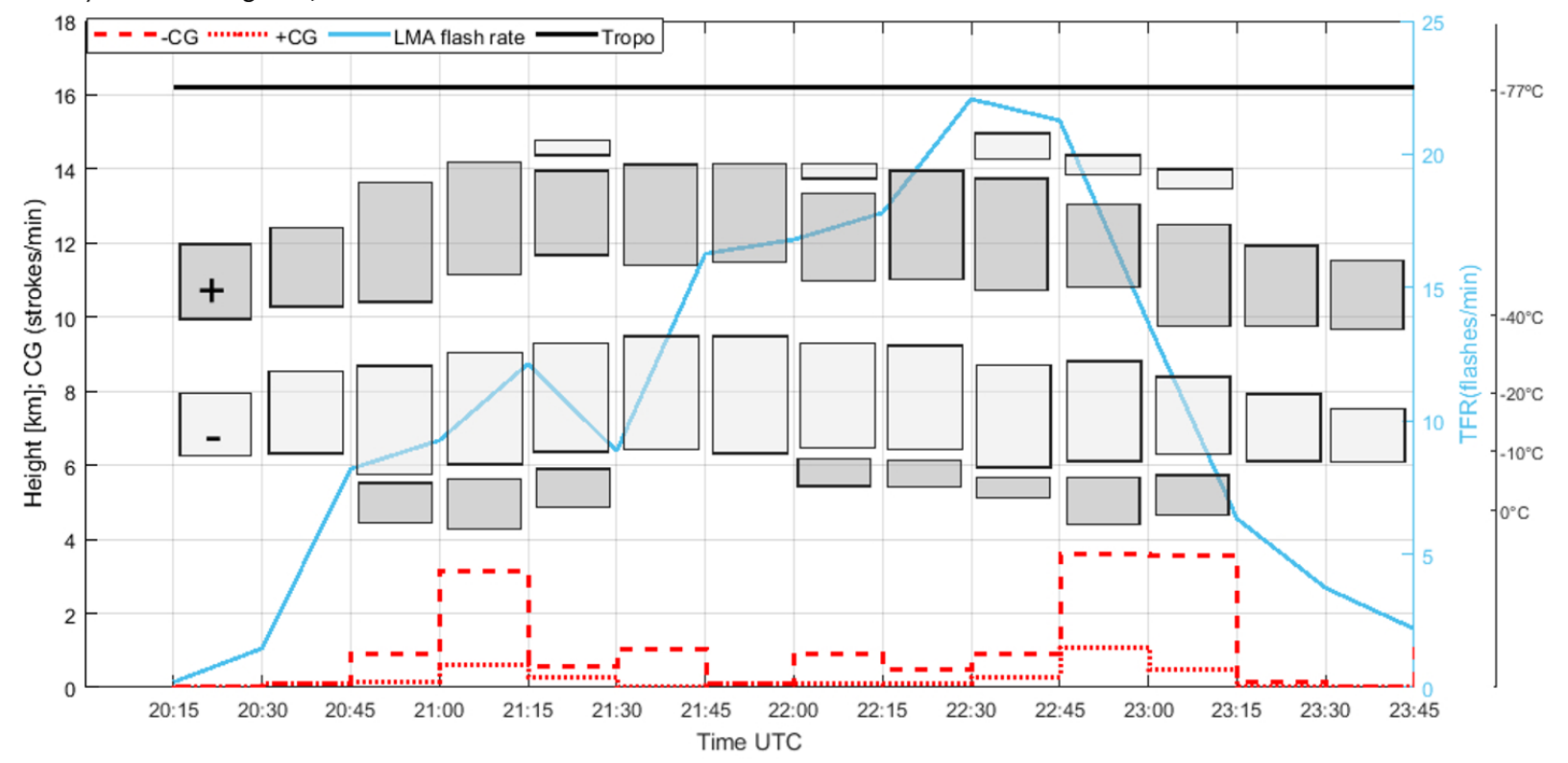


Figure 5.
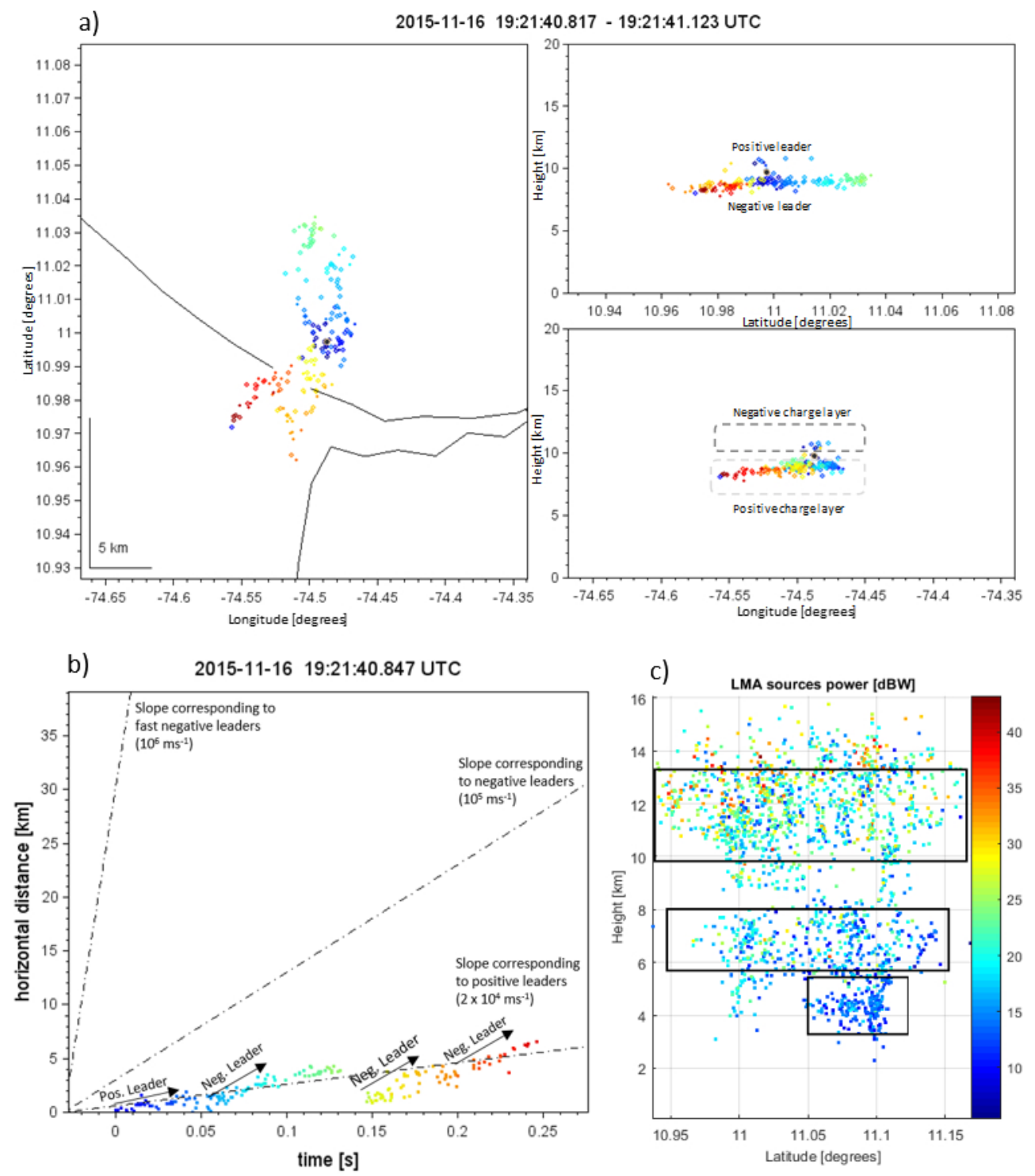
Figure 6.
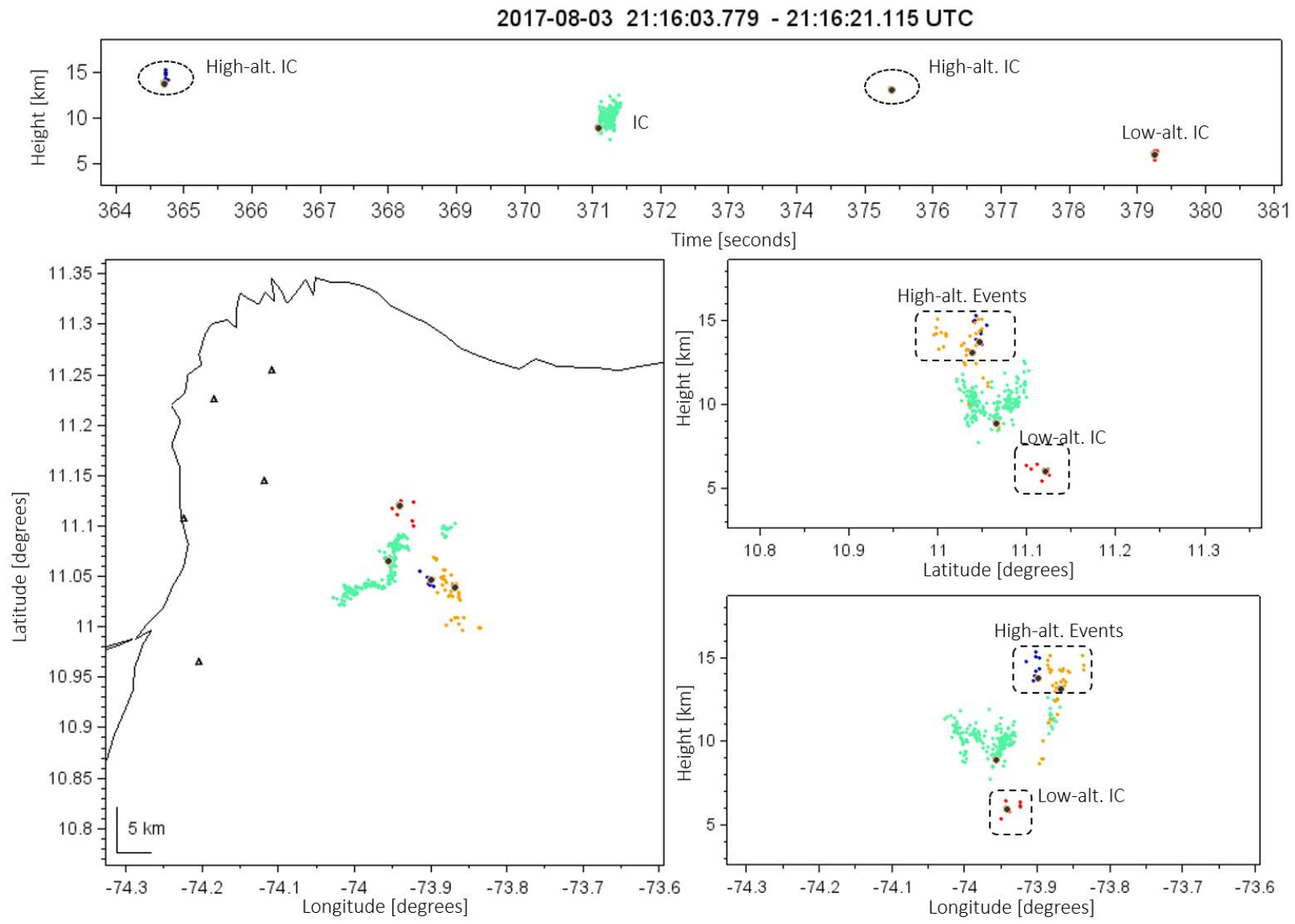